\title{
Identifying barriers that affect medical doctors' learning of dental trauma
}

\author{
Thai Yeng ${ }^{1}$, Anthony J O'Sullivan ${ }^{2}$, and Boaz Shulruf ${ }^{3}$ \\ 1. Medical Education, Faculty of Medicine, UNSW, Australia \\ 2. St George and Sutherland Clinical School, UNSW, Australia \\ 3. Medical Education, Faculty of Medicine, UNSW, Australia
}

\section{RESEARCH}

Please cite this paper as: Yeng T, O'Sullivan AJ, Shulruf B. Identifying barriers that affect medical doctors' learning of dental trauma. AMJ 2020;13(1):26-31.

https://doi.org/10.35841/1836-1935.13.1.26-31

\section{Corresponding Author:}

Dr Thai Yeng

University of New South Wales, Faculty of Medicine, Office of Medical Education, UNSW Sydney, NSW, 2052, Australia

ORCID: 0000-0001-6244-668X

Email: dr.thai.yeng@gmail.com

\section{ABSTRACT}

\section{Background}

It is important that medical doctors are familiar with the management of emergency dental trauma before referring a patient to a dentist. Correct diagnosis and treatment techniques are essential for a predictable and optimal longterm prognosis.

\section{Aims}

The aim is to identify and categorize statements from the literature related to barriers (factors that hinder learning) on dental trauma for medical doctors.

\section{Methods}

The authors reviewed ten papers pertaining to medical doctors' knowledge of dental trauma and identify some common barriers to learning.

\section{Results}

The barriers identified were classified as internal (factors associated with the learner) or external (factors associated with the learning environment). Internal barriers negatively impact learners and may cause medical doctors to lose enthusiasm or interest in the subject. External barriers, on the other hand, often arise from within the university or teaching hospital and may affect medical students' and doctors' theoretical learning of dental trauma or hamper their clinical experience.

\section{Conclusion}

From a limited body of literature, this report has identified some common barriers that affect doctors' learning of dental trauma. Consequently, to further investigate the relevance of these barriers and their impact on dental trauma learning, a systematic review in this area is indicated.

\section{Key Words}

Barriers, learning, dental trauma, medical education, medical doctors

\section{Implications for Practice:}

\section{What is known about this subject?}

A review of the literature suggests that there is a general deficiency in knowledge and confidence levels amongst medical doctors for managing dental trauma.

\section{What new information is offered in this report?}

This report grouped barriers to learning dental trauma by medical doctors into internal and external categories.

3. What are the implications for research, policy, or practice?

Any proposal for educational change may take time to achieve an impact on medical doctors' learning outcomes. Further investigation with a systematic review is indicated.

\section{Background}

Dental trauma can be direct or indirect. Direct trauma occurs when the tooth itself is traumatized, and indirect trauma occurs when the lower arch (the mandibular teeth) is forcefully impacted against the upper arch (the maxillary teeth). ${ }^{1}$ Dental trauma can range from simple concussions to extensive maxillofacial damage with root displacements or 
tooth avulsion. ${ }^{2}$ The economic impact of delaying the survival of the traumatized teeth is significant, largely because tooth replacements are financially straining and mentally exhausting for patients. ${ }^{3}$ It is very important that medical doctors set appropriate treatment priorities for dental trauma because certain conditions need acute management (within a few hours); for example, tooth avulsion, alveolar fracture, and root fracture. Other conditions, such as intrusion, concussion, subluxation and crown fractures with pulp exposure, may need treatment within the first 24 hours (sub-acute). ${ }^{4}$ Emergency treatments may involve repositioning a luxated tooth to its original position or replanting an avulsed tooth using splinting techniques, as well as managing pain with analgesics etc. before referring to the dentist for on-going care. ${ }^{5}$

Inadequate knowledge and a lack of skills and confidence in providing suitable care to dental trauma patients can be partly attributed to the non-existence or at best minimal dental education in the medical curriculum. ${ }^{6}$ Teaching medical students to understand and manage dental trauma is important ${ }^{5}$ to significantly increase in the knowledge base and skills required for medical doctors to manage these problems. ${ }^{6}$ It has been suggested that integrating dental trauma into the medical education program will provide essential knowledge and management skills for doctors. ${ }^{7}$

The aim of this review is to identify the important barriers (factors that inhibit learning) that may impact the understanding and management of dental trauma by medical doctors.

\section{Methods}

Drawing on the ten studies listed in the scoping review by Yeng et $\mathrm{al}^{6}{ }^{6}$ the purpose of this review is to identify barriers to learning about dental trauma for medical doctors. The data obtained from these studies should be interpreted with caution due to the diversity of context and methodological variability, such as study and questionnaire design, response rates, and methods of statistical analysis and data processing. Although the authors have endeavoured to find the most relevant barriers to learning for medical doctors, they cannot guarantee that every barrier associated with this subject has been identified. Studies were eligible for inclusion if they were peer-reviewed, English language journal articles or published conferences papers, reported qualitative or quantitative analysis, and included participants comprising any of the following participants: medical doctors, medical physicians and medical specialists. Studies from any geographical location were included (Table 1).

\section{Results}

The identified barriers were categorized as internal or external. The authors considered "something within medical learners' that prevents them from reaching their goal as internal barrier". Whereas an "external barrier is something in the medical learner's environment that prevents them from reaching their goal". ${ }^{8}$ A summary of the findings for internal and external barriers is shown in Table 2.

\section{Internal barriers}

The three most common findings related to personal attitude, a lack of information, and personal concerns. Personal attitude included low levels of awareness towards dental trauma; ${ }^{9-11}$ lack of motivation for learning dental trauma management; ${ }^{12}$ disinterested in seeking dental advice; ${ }^{12,13}$ harbouring attitudes that dental trauma should be managed by dentists; ${ }^{12,14}$ low confidence; ${ }^{13-18}$ and avoidance due to the legal implications in managing dental trauma. ${ }^{13}$ The lack of information theme included: medical doctors being more concerned about bleeding from the alveolus than prolonging the survival of the tooth itself; ${ }^{12,15}$ giving poor advice due to a lack of knolwedge $;^{9,13,15-17}$ a lack of unawareness of dental clinics that can help manage dental trauma ${ }^{13,16}$ and a lack of clinical experience. ${ }^{15,16}$ Personal concerns included issues such as a lack of confidence on the success of treatment; ${ }^{10}$ management of patient behavioural issues requiring sedation for certain dental cases; ${ }^{16}$ and how to deal with serious concomitant maxillofacial trauma cases. ${ }^{16}$

\section{External barriers}

Three findings were identified as external barriers; namely, a lack of support, lack of information and a lack of training. The lack of support included no in-house dental services; ${ }^{9,10,16}$ dental trauma cases being routinely referred out for management; $;^{9,10,17}$ and no dental referral list for dental support. ${ }^{13,17}$ The lack of information theme included: the lack of written protocol or instructions within hospital facilities; ${ }^{10,11,16,17}$ the application of incorrect protocol instructions; $^{10}$ a lack of formal education; $;, 9-11,13-15,17$ no dental teaching during medical school; ${ }^{9,13,14,17,18}$ and dental trauma being excluded from medical texts or first-aid manuals. ${ }^{16-18}$ Under lack of training, the issues included: a lack of postgraduate training; $;^{9,11,13-18}$ a lack of clinical exposure to, and experience of, dental trauma; ${ }^{9,17,18}$ a lack of validated training; ${ }^{9,13,17}$ inadequate management time and allocated resources to treat dental injuries; ${ }^{15-17}$ and an absence of dental trauma in emergency residency training programs. $^{17}$ 


\section{Discussion}

This paper identified barriers that may interact with medical doctors learning of dental trauma. Any factor that negatively affects a medical students' or doctors' learning outcome may be a "barrier to learning". These barriers have been classified as either internal (factors related to the learner) or external (factors outside the learners' control). In relation to internal barriers, awareness of medical students' and doctors' views about preferred learning approaches may enable decision makers at institutions or local educational organizations to consider more suitable teaching methods to improve knowledge and confidence in dental trauma. Similarly, by identifying common institutional barriers to learning dental trauma, medical educators will be able to alleviate some of the external barriers medical students and doctors face.

The findings from this review support the notion that internal barriers may negatively impact the medical learner causing them to lose enthusiasm and interest in dental trauma education. That many doctors have not been trained in dental trauma assessment and management ${ }^{17}$ results in many medical doctors being unaware of the urgency of emergency care for dental trauma patients, the importance of managing dental injuries appropriately, ${ }^{9-11}$ or the clinical relevance of prolonging the survival of a traumatized tooth. ${ }^{5}$ For example, losing a traumatized tooth at an early age may result in a young patient wearing a temporary prosthesis, like a denture, for many years until they reach an age, and jaw development stage, for a dental implant placement to take place. If medical doctors are not provided with the learning resources and environments that establish traumatic dental injuries as an interesting and important subject, then it is not surprising that many medical doctors are unmotivated $^{13}$ and not interested ${ }^{12,13}$ in becoming competent in managing dental trauma. A physician's personal view that studying dental trauma is unappealing becomes a barrier to further learning.

A possible reason for why medical doctors avoid treating traumatic dental injuries could be that when a patient presents with acute dental trauma, the patient may also have other urgent medical conditions that require immediate attention. ${ }^{19}$ For example, soft tissue lacerations, reduced consciousness, vomiting and localized fractures of the jaw, or injury to the eye etc. Whilst a systematic history, clinical examination and preliminary investigation must take place to aid in the assessment of the extent of the overall injury, $^{20}$ this assessment may not necessarily involve the traumatized tooth or teeth. Another possible reason for medical doctors avoiding the treatment of dental trauma could be that the patient is uncooperative due to the trauma of the accident, illness, intoxication or drug use. For these reasons, medical doctors may have concerns about the lack of assurance they can give to patients on the success of treating dental injuries and the prognosis of the injury, ${ }^{13}$ due to insufficient clinical knowledge. ${ }^{9,13,15-17}$ This lack of knowledge can result in a fear of future legal action ${ }^{13}$ and thus influence their decision to refer the dental injury for treatment and follow-up by a dentist or specialist. ${ }^{12,14}$ By repeatedly avoiding dental trauma treatment, there is the potential that medical doctors may develop a lack of selfconfidence in managing dental trauma. ${ }^{5}$

A possible action plan to address these internal barriers might be to engage a dentist or dental specialist, with dental trauma knowledge and experience, to work alongside the academic staff in medical schools to develop relevant dental trauma curricula and teaching resources for staff and medical students. The objective would be to minimize or eliminate internal learning barriers so medical students are more likely to find dental trauma an interesting and acceptable topic. Though greater engagement they are more likely to increase their knowledge and awareness of traumatic dental injuries and raise their self-confidence before graduating as medical doctors as well as encourage future learning in this subject.

External barriers are inhibiting factors that are independent of the learner and can stand in the way of effective teaching and effective theoretical learning of dental trauma at the university or hamper clinical experience at the teaching hospital for medical students and doctors. These inhibiting factors arise independently of the medical learner and impact on their learning. This review suggests that, on the topic of dental trauma, no formal protocol or written instructions, ${ }^{10,11,16,17}$ no formal education provision, ${ }^{9-11,13-15,17}$ a lack of formal postgraduate training ${ }^{9,11,13-15,17,18}$ and no clinical dental teaching during medical studies $9,13,14,17,18$ act as barriers for medical doctors' dental trauma learning. With such a gap in learning provision, it is not surprising that very few medical doctors show high levels of knowledge for assessing and managing dental trauma. ${ }^{5}$ While medical doctors should not be overburdened with dental management knowledge and skills, having basic knowledge and skills to safely treat and stabilize a dental trauma case would be useful. ${ }^{6}$ These are important skills for doctors to obtain early on in their career. Formal lectures, organized seminars and continuing education courses for physicians are all suitable avenues for physicians to gain the necessary understanding. ${ }^{5}$ There are also comprehensive guidelines available for doctors to easily access when required, such as 
management guidelines; manuals on dental trauma management; textbooks and colour atlases on traumatic injuries to teeth; and published journal articles on dental traumatology. ${ }^{21}$ A lack of clinical experience can, however, also impact on the medical doctors' dental trauma learning. It is reported that both a lack of clinical exposure and experience ${ }^{14,17,18}$ and a lack of approved training courses on the management of traumatic dental injuries ${ }^{13,14,17}$ act as a barrier to learning for medical doctors.

For medical doctors to learn about dental trauma more effectively, extrinsic barriers need to be minimized. One possible plan of action is the development of a dental trauma unit within medical teaching hospitals. Having patients present at the unit with a range of traumatic dental injuries will provide medical students with greater exposure to dental trauma cases. In addition, it will allow medical doctors to gain clinical experience in managing a wide range of dental injuries and the opportunity to discuss their treatment with dentists and dental specialists employed in the dental trauma unit. The concept of establishing a specialist dental trauma unit within major teaching hospitals is also likely to have a positive impact on patients' treatment, allowing a multidisciplinary approach to managing dental traumatic injuries.

\section{Conclusion}

This review has identified common barriers to learning dental trauma by medical doctors. Highlighting these barriers provides medical educators with greater awareness to address them and create more positive environments that impact the individual learner. Due to the limitations of this review, a systematic review is indicated in this area to further investigate the relevance of barriers and their impact on learning dental trauma for medical doctors.

\section{References}

1. Welbury RR. Paediatric Dentistry, Chapter 11, Traumatic Injuries to the Teeth. Press OU, editor. Oxford University Press, Great Clarendon Street, Oxford, OX2 6DP, New York: Oxford University Press; 2003:221-50.

2. Andreasen JO, Lauridsen E, Gerds TA, et al. Dental Trauma Guide: a source of evidence-based treatment guidelines for dental trauma. Dent Traumatol. 2012;28:142-7.

3. Yeng T, O'Sullivan AJ, Shulruf B. Appropriate management of traumatic dental injuries at the hospital emergency department provides a positive impact on patient outcomes: exemplar case study. AMJ. 2019;12:255-62.
4. Andreasen JO, Andreasen FM, Blakland LK, et al. Traumatic Dental Injuries A Manual 2nd Edition. Munkgaard B, editor. Blackwell Publishing Ltd, Oxford, OX4 2DQ, UK: Blackwell Publishing Ltd; 2003:26-7.

5. Yeng T, O'Sullivan AJ, Shulruf B. Learning about dental trauma for medical students. Dent Traumatol. 2019. doi: 10.1111/edt.12530

6. Yeng T, O'Sullivan AJ, Shulruf B. Medical doctors' knowledge of dental trauma management: A review. Dent Traumatol. 2019. https://doi.org/10.1111/edt.12518

7. Yeng T, O'Sullivan AJ, Shulruf B. A proposal to introduce dental trauma into medical education: An insight. Dent Traumatol. 2020. doi: 10.1111/edt.12542.

8. Falasca M. Barriers to adult learning: Bridging the gap. Australian Journal of Adult Learning. 2011;51:583-590.

9. Ulusoy $A T$, Onder $H$, Cetin $B$, et al. Knowledge of medical hospital emergency physicians about the first-aid management of traumatic tooth avulsion. Int J Paediatr Dent. 2012;22:211-6.

10. Holan G, Shmueli Y. Knowledge of physicians in hospital emergency rooms in Israel on their role in cases of avulsion of permanent incisors. Int J Paediatr Dent. 2003;13:13-9.

11. Abu-Dawoud M, Al-Enezi B, Andersson L. Knowledge of emergency management of avulsed teeth among young physicians and dentists. Dent Traumatol. 2007;23:34855.

12. Subhashraj K. Awareness of management of dental trauma among medical professionals in Pondicherry, India. Dent Traumatol. 2009;25:92-4.

13. Aren A, Erdem AP, Aren G, et al. Importance of knowledge of the management of traumatic dental injuries in emergency departments. Ulus Travma Acil Cerrahi Derg. 2018;24:136-44.

14. Trivedy C, Kodate N, Ross A, et al. The attitudes and awareness of emergency department (ED) physicians towards the management of common dentofacial emergencies. Dent Traumatol. 2012;28:121-6.

15. Raoof M, Vakilian A, Kakoei S, et al. Should medical students be educated about dental trauma emergency management? A study of physicians and dentists in Kerman Province, Iran. J Dent Educ. 2013;77:494-501.

16. Needleman HL, Stucenski K, Forbes PW, et al. Massachusetts emergency departments' resources and physicians' knowledge of management of traumatic dental injuries. Dent Traumatol. 2013;29:272-9.

17. Yigit $Y$, Helvacioglu-Yigit D, Kan B, et al. Dentofacial traumatic injuries: A survey of knowledge and attitudes among emergency medicine physicians in Turkey. Dent Traumatol. 2019;35:20-6. 
18. Cruz-da-Silva BR, Perazzo Mde F, Neves ET, et al. Effect of an educational programme on the knowledge level among an emergency service medical team regarding tooth avulsion. Oral Health Prev Dent. 2016;14:259-66.

19. Andreasen JO, Andreasen FM, Andersson L. Textbook and Colour Atlas of Traumatic Injuries to the Teeth, 4th Edition, Chapter 9, Examination and Diagnosis of Dental Injuries. Ltd BP, editor: Blackwell Publishing Ltd, Oxford, OX4 2DQ, UK; 2007:255-74.

20. Yeng T, Parashos P. An investigation into dentists' management methods of dental trauma to maxillary permanent incisors in Victoria, Australia. Dent Traumatol. 2008;24:443-8.

21. Yeng T, O'Sullivan AJ, Shulruf B. Dental trauma learning facilitators for medical doctors: a viewpoint. Dent Traumatol. 2020. doi: 10.1111/edt.12541.

\section{ACKNOWLEDGEMENTS}

None

\section{PEER REVIEW}

Not commissioned. Externally peer reviewed.

\section{CONFLICTS OF INTEREST}

The authors declare that they have no competing interests.

\section{FUNDING}

Not applicable

\section{ETHICS COMMITTEE APPROVAL}

Not applicable

\section{Figures and Tables}

Table 1: Studies used in identifying barriers to learning dental trauma for medical doctors, adapted from Yeng et al. ${ }^{6}$

\begin{tabular}{|l|l|l|}
\hline \multicolumn{1}{|c|}{ Studies } & $\begin{array}{l}\text { Location, study type } \\
\text { and year }\end{array}$ & Reference \\
\hline $\begin{array}{l}\text { Knowledge of physicians in hospital } \\
\text { emergency rooms in Israel on their } \\
\text { role in cases of avulsion of } \\
\text { permanent incisors }\end{array}$ & Israel, Survey, 2003 & {$[10]$} \\
\hline $\begin{array}{l}\text { Knowledge of emergency } \\
\text { management of avulsed teeth } \\
\text { among young physicians and } \\
\text { dentists }\end{array}$ & Kuwait, Survey, 2007 & {$[11]$} \\
\hline $\begin{array}{l}\text { Awareness of management of } \\
\text { dental trauma among medical } \\
\text { professionals in Pondicherry, India }\end{array}$ & India, Survey, 2009 & {$[12]$} \\
\hline
\end{tabular}

\begin{tabular}{|l|l|l|}
\hline $\begin{array}{l}\text { The attitudes and awareness of } \\
\text { emergency department (ED) } \\
\text { physicians towards the } \\
\text { management of common } \\
\text { dentofacial emergencies }\end{array}$ & $\begin{array}{l}\text { United Kingdom, } \\
\text { Survey, 2012 }\end{array}$ & [14] \\
\hline $\begin{array}{l}\text { Knowledge of medical hospital } \\
\text { emergency physicians about the } \\
\text { first-aid management of traumatic } \\
\text { tooth avulsion }\end{array}$ & Turkey, Survey, 2011 & [9] \\
\hline $\begin{array}{l}\text { Should medical students be } \\
\text { educated about dental trauma } \\
\text { emergency management? A study } \\
\text { of physicians and dentists in } \\
\text { Kerman province, Iran }\end{array}$ & Iran, Survey, 2013 & [15] \\
\hline $\begin{array}{l}\text { Massachusetts emergencies } \\
\text { departments' resources and } \\
\text { physicians' knowledge of } \\
\text { management of traumatic dental } \\
\text { injuries }\end{array}$ & 2013 & America, Survey, \\
\hline $\begin{array}{l}\text { Importance of knowledge of the } \\
\text { management of traumatic dental } \\
\text { injuries in emergency departments. }\end{array}$ & Turkey, Survey, 2018 \\
\hline $\begin{array}{l}\text { Dentofacial traumatic injuries: A } \\
\text { survey of knowledge and attitudes } \\
\text { among emergency medicine } \\
\text { physicians in Turkey. }\end{array}$ & Turkey, Survey, 2019 \\
\hline Erazil, Survey, 2016 & [18] \\
\hline
\end{tabular}

Table 2: A summary of the findings for internal and external barriers

\begin{tabular}{|c|c|c|}
\hline Type of Factors & Findings & Reference \\
\hline $\begin{array}{l}\text { Internal } \\
\text { barriers }\end{array}$ & & \\
\hline \multirow{6}{*}{$\begin{array}{l}\text { Personal } \\
\text { attitude }\end{array}$} & $\begin{array}{l}\text { Doctors report a low awareness } \\
\text { on saving teeth }\end{array}$ & {$[9-11]$} \\
\hline & $\begin{array}{l}\text { Doctors are not motivated in } \\
\text { seeking dental trauma knowledge }\end{array}$ & [12] \\
\hline & $\begin{array}{l}\text { Doctors are not interested to seek } \\
\text { advice on dental injuries }\end{array}$ & {$[12,13]$} \\
\hline & $\begin{array}{l}\text { Doctors believe acute dental } \\
\text { traumatic injuries should be } \\
\text { managed by dentists }\end{array}$ & {$[12,14]$} \\
\hline & $\begin{array}{l}\text { Doctors report low confidence in } \\
\text { dealing with dental trauma }\end{array}$ & [13-18] \\
\hline & $\begin{array}{l}\text { Doctors do not wish to manage } \\
\text { dental trauma for legal reasons }\end{array}$ & [13] \\
\hline \multirow{3}{*}{$\begin{array}{l}\text { Personal } \\
\text { concerns }\end{array}$} & $\begin{array}{l}\text { Doctors are concerned about no } \\
\text { assurance on success of treatment }\end{array}$ & [10] \\
\hline & $\begin{array}{l}\text { Doctors worry about behavioural } \\
\text { management issues that requires } \\
\text { sedation for certain dental cases }\end{array}$ & {$[16]$} \\
\hline & $\begin{array}{l}\text { Doctors are concerned about } \\
\text { serious concomitant maxillofacial } \\
\text { trauma cases involving multiple } \\
\text { teeth }\end{array}$ & {$[16]$} \\
\hline
\end{tabular}




\begin{tabular}{|c|c|c|}
\hline \multirow{4}{*}{$\begin{array}{l}\text { Lack of } \\
\text { information }\end{array}$} & $\begin{array}{l}\text { Doctors are more concerned } \\
\text { about bleeding from the alveolus } \\
\text { than the tooth itself }\end{array}$ & {$[12,15]$} \\
\hline & $\begin{array}{l}\text { Doctors worry about giving poor } \\
\text { advice due to insufficient } \\
\text { knowledge on managing dental } \\
\text { injuries }\end{array}$ & {$[9,13,15-17]$} \\
\hline & $\begin{array}{l}\text { Doctors lack awareness of } \\
\text { emergency dental clinics that } \\
\text { manage dental trauma }\end{array}$ & {$[13,16]$} \\
\hline & $\begin{array}{l}\text { Doctors report a lack of clinical } \\
\text { knowledge in identifying primary } \\
\text { and permanent dentition }\end{array}$ & {$[15,16]$} \\
\hline \multicolumn{3}{|l|}{$\begin{array}{l}\text { External } \\
\text { barriers }\end{array}$} \\
\hline \multirow{3}{*}{ Lack of support } & $\begin{array}{l}\text { Dental trauma cases are routinely } \\
\text { referred out for management }\end{array}$ & {$[9,10,17]$} \\
\hline & $\begin{array}{l}\text { No in-house dental services are } \\
\text { available to support medical } \\
\text { doctors }\end{array}$ & {$[9,10,16]$} \\
\hline & $\begin{array}{l}\text { No referral list of dentists or } \\
\text { dental specialists is provided for } \\
\text { doctors }\end{array}$ & {$[13,17]$} \\
\hline \multirow{5}{*}{$\begin{array}{l}\text { Lack of } \\
\text { information }\end{array}$} & $\begin{array}{l}\text { No formal protocol or written } \\
\text { instructions on managing dental } \\
\text { trauma injuries from the hospital } \\
\text { facility are provided }\end{array}$ & {$[10,11,16,17]$} \\
\hline & $\begin{array}{l}\text { Medical doctors at hospital follow } \\
\text { incorrect protocol instructions }\end{array}$ & [10] \\
\hline & $\begin{array}{l}\text { Medical doctors receive no formal } \\
\text { education on the topic of dental } \\
\text { trauma }\end{array}$ & $\begin{array}{l}{[9-11,13-} \\
15,17]\end{array}$ \\
\hline & $\begin{array}{l}\text { Clinical dentistry is not taught } \\
\text { during medical undergraduate } \\
\text { training }\end{array}$ & {$[9,13,14,17,18]$} \\
\hline & $\begin{array}{l}\text { Dental trauma and its } \\
\text { management are not included in } \\
\text { medical text or first-aid manuals }\end{array}$ & [16-18] \\
\hline \multirow{5}{*}{ Lack of training } & $\begin{array}{l}\text { There is a lack of formal } \\
\text { postgraduate training on the area } \\
\text { of dental trauma }\end{array}$ & {$[9,11,13-18]$} \\
\hline & $\begin{array}{l}\text { There is a lack of exposure to, and } \\
\text { experience of, the various dental } \\
\text { trauma injuries }\end{array}$ & {$[9,17,18]$} \\
\hline & $\begin{array}{l}\text { There is a lack of validated training } \\
\text { on the area of dental trauma } \\
\text { management }\end{array}$ & {$[9,13,17]$} \\
\hline & $\begin{array}{l}\text { There is a lack of time and } \\
\text { resources for doctors to } \\
\text { adequately manage dental trauma } \\
\text { cases. }\end{array}$ & {$[30,35,36]$} \\
\hline & $\begin{array}{l}\text { Training of emergency doctors in } \\
\text { residency programs is incomplete } \\
\text { with the absence of dental trauma } \\
\text { teaching }\end{array}$ & [17] \\
\hline
\end{tabular}

